\title{
AN INVESTIGATION OF SOME TOMATO DISEASES.
}

\author{
By F. T. Brooks, M.A. and G. O. Searle, B.Sc.
}

In January I9I3 a paper(2) was published by the senior author and another giving an account of a disease of tomatoes, isolated from the fruit and stems of plants grown out-of-doors.

This disease was identified by the late $\mathrm{Mr}$ Massee, as " $A$ scochyta citrullina C. O. Sm., the conidial form of Mycosphaerella citrullina Gross." which was also the name given by this authority (9) to the fungus causing an epidemic disease ("canker") of tomato stems in glass houses. In recent years this disease has been infrequent in English tomato houses, but it appeared in epidemic form in Holland during IgIg where it has been described by Schoevers(I4) under the same name.

During the years I9II to I9I9 one of the writers collected various forms of fruit rots of tomatoes, and isolated the causal fungi. In August Igr9 a detailed examination of these organisms was commenced and it seems desirable to place on record the results of this investigation obtained to date. During the early part of the joint investigation a few additional forms were collected by the junior author and included with the others.

Certain cultures and herbarium specimens were also obtained from various sources, and it will be convenient to tabulate here the origin of all the material used.

A. Phoma destructiva (Plowr.) C. O. Jamieson(7). This was an authentic culture obtained from the Department of Agriculture, Washington, D.C., in the summer of r9r6 through the kindness of Dr C. L. Shear.

$B$. A culture of a pycnidial form of fungus from a rotten out-door tomato fruit collected at Merton, on September I 7 th, I9I5.

C. A culture of a fungus showing both a pycnidial form of fructification and also spores of an Alternaria type on the same mycelium, obtained from a rotten tomato fruit collected at Bristol on January 25th, I916. This fruit was one of a number purchased at a shop.

D. Colletotrichum phomoides (Sacc.) Chest. This was an authentic culture obtained from New York originally, but it was passed through tomato fruits and re-isolated in the autumn of I9I5.

E. A culture of a pycnidial form of fungus from a rotten 
tomato found lying on the ground at the Cambridge University farm on October 5 th, I9I6.

$F$. A culture of a pycnidial form of fungus from a tomato fruit, partly green, partly rotten, found at the same time and place as $E$.

$G$. A culture of a pycnidial form of fungus from a half-rotten tomato fruit collected at the same place and time as $E$ and $F$, and only differing from them in that no pycnidia developed until it had been kept for some days in the laboratory. This culture was found to produce pycnidia and spores very sparingly and was later discarded as it was not found possible to obtain a single-spore culture from it. In the preliminary examination no difference from $E$ and $F$ could be detected, except that the spores were generally slightly smaller.

$H$. A culture of a pycnidial form of fungus from a rotten tomato (one of seven) collected in a garden at Cambridge, November 2nd, I9I6.

$I$. This form was discarded.

$J$. A culture of a pycnidial form of fungus from a rotten half-ripe tomato collected at Cambridge, September I9I8.

$K$. A culture of a Gloeosporium or Colletotrichum from a rotten half-ripe tomato collected at Cambridge, September I9I8.

$K 2$. A culture of a Gloeosporium or Colletotrichum which appeared in the laboratory on an apparently sound ripe tomato, which had been inoculated with "A" in October I9r9.

L. A culture of a pycnidial form of fungus from a diseased tomato bought in the market at Cambridge on January I7th, I9I9.

$M$. A culture of a pycnidial form of fungus from a shrivelled tomato collected out-of-doors at Cambridge, March IgIg.

$N$. A culture of a Fusarium from a rotten tomato collected at Longstowe, Cambridgeshire, August I9rg.

$O$. This was discarded.

$P$. A culture of a pycnidial form of fungus from a suncracked tomato collected out-of-doors at Longstowe, October I9I9.

Q. A culture of a pycnidial form of fungus from a rotten tomato collected out-of-doors at Longstowe, October IgI9.

$R$. This was discarded.

$S$. A culture of a Colletotrichum from a rotten tomato collected at Cambridge, December I9I9.

T. Ascochyta Pisi Lib. A culture from the Centralstelle für Pilzkulturen, Amsterdam.

U. Mycosphaerella citrullina (C. O. Sm.) Gross. An authentic culture kindly furnished by Dr C. L. Shear of the United States Department of Agriculture in the autumn of rgrg. This was 
Some Tomato Diseases. F. T. Brooks and G. O. Searle. 175

originally collected at Detroit, Michigan from a cucumber grown in Florida. To date no fructifications have formed on any of the media used so that it has not been possible to make a single-spore culture.

The herbarium specimens examined for the purpose of this investigation were as follows:

I. Mycosphaerella citrullina on tomato stem collected at Cheshunt, June Ist, I9II, kindly supplied by Mr A. D. Cotton, Ministry of Agriculture, Herbarium No. A I 4405.

2. Mycosphaerella citrullina on tomato stem collected at Finchley, July I9I5. From the same source as No. I, Herbarium No. A 25208.

3. Mycosphaerella citrullina (C. O. Sm.) Gross. on watermelon stem, collected at Lakeland, Fla., U.S.A., in April I9I9, kindly sent by Dr C. L. Shear.

4. Mycosphaerella citrullina (C. O. Sm.) Gross. on watermelon from Florida, collected in New York market, May I9I9; also sent by Dr C. L. Shear.

5. Mycosphaerella citrullina Gross. on tomato stem collected by A. A. Wills at Cheshunt, September I6th, I9Io; in the Kew herbarium (6).

6. Mycosphaerella citrullina Gross. on tomato stem collected by F. Hearnum at Waltham Cross on June 14th, I909; in the Kew Herbarium.

7. Mycosphaerella citrullina Gross. on the lower part of melon stem, collected by I. W. Read at Norwich, September I9I2; in the Kew Herbarium.

8. Phoma Lycopersici Cke. on tomato stem. Collected by J. E. Vize (circa I884?); in the Kew Herbarium.

9. Diplodina citrullina (Sm.) Gross. Collected in Brandenburg "auf trockenen Ranken von Cucumis sativus" by P. Vogel, December I8th, I908; from Sydow's "Mycotheca germanica"; in the Herbarium of the British Museum.

IO. Mycosphaerella citrullina (C. O. Sm.) Gross. on cucumber fruit collected in Florida, May rgI7. Received from Dr C. L. Shear(5).

An effort was also made to obtain Plowright's type specimens of Phoma destructiva and Sphaeronema Lycopersici(9) but these were not forthcoming*.

A detailed investigation of the cultural and other characteristics of the various forms isolated was commenced in August I9I9. In the preliminary cultural trials "pure cultures". were used but not "single-spore" cultures; single-spore cultures were

* We are indebted to Mr W. B. Grove for kindly searching for these specimens in Plowright's herbarium, which is now in the Botanical Department of Birmingham University. 
isolated later and were used throughout the remainder of the investigation. The cultures and inoculations were made and maintained at ordinary laboratory temperatures.

\section{PRELIMINARY INOCULATIONS AND CULTURE EXPERIMENTS.}

A preliminary series of inoculations and culture experiments were carried out, using the various forms as isolated on tomato agar. Twelve forms were used, namely: $A, B, C, D, E, F, G$, $H, J, K, L, M$, which were the only ones available at the time. The following hosts and artificial media were employed with a view to obtaining a general idea of the characteristics of the various forms and to discover, if possible, some medium which would give a maximum spore formation, before proceeding to the isolation of single-spore cultures and a final comparison of the various forms.

Series $A$ consisted of inoculations into nearly ripe tomato fruits kept in a large glass dish in the laboratory. Two cuts were made with a sterile scalpel in each fruit and a fragment of mycelium introduced from each culture. Control tomato fruits were cut but not inoculated.

In each case a rot of the fruit commenced by the fourth day, except in the controls which remained healthy. All the forms were then successfully re-isolated on to tomato agar from the fruits. Descriptions of the appearance of these fungi on tomato fruits are given later.

Series $E$ consisted of inoculations of pieces of petiole of vegetable marrow, sterilised and kept in tubes at laboratory temperature. On this substratum all the various forms grew luxuriantly and spores were freely produced.

Series $G$ consisted of inoculations into stems of living tomato plants in a greenhouse. Mycelium was inserted into a slit in the stem and the wound was then bound up with tin-foil. In the case of Form $L$ a large canker was formed about $2 \frac{1}{2}$ inches long, which spread also to the base of adjacent branches. Large numbers of pycnidia were visible, and re-isolation on to tomato agar was carried out giving Form $L$ again. In all the other inoculations there was a slight discoloration of the stem, but no cankers were formed nor was there any trace of pycnidia.

Series $K$ consisted of inoculations on to sterilised potato cores,

Series $L$ on to sterilised potato cores plus I \% glycerine, and

Series $M$ on to potato agar; these three media were used to try to discover one which would give a uniform production of fruiting bodies of the various forms. However, none of them was particularly successful, though all the various forms developed on these media to a greater or less extent as far as the 
Some Tomato Diseases. F. T. Brooks and G. O. Searle. 177

mycelial stage was concerned. The mycelium was more scanty on potato agar than on the other two media.

Series $N$ was undertaken to test the pathogenicity of these twelve forms on the fruit of the vegetable marrow. A large fruit was selected and vertical slits about one inch apart were made round the circumference, into which the various forms were inoculated. In no case did a positive infection occur.

A few other preliminary experiments were made and will be briefly mentioned here.

Inoculations with forms $C, J$, and $M$ were made into pears under bell jars in the laboratory, pears with sterile cuts and tomato fruits with inoculations of $C, J$ and $M$ being used as controls. Typical rots with abundant pycnidia were formed on the control tomato fruits, but in the pears no rot was caused by Form $C$, whilst Forms $J$ and $M$ both formed large soft brown rots although no mycelium nor pycnidia showed on the surface.

Preliminary experiments were then tried for the purpose of indicating whether the various forms were wound or non-wound parasites of tomato fruits. It was found that the finest prick on the surface was sufficient to allow the entry of the fungus when spores were sown on the surface, but infection never resulted when spores were sown on the uninjured surface, even when spores were sown in a drop of ro \% sugar solution to assist germination or when mycelium was placed on the surface of the fruit in a fragment of tomato agar.

Spore suspensions of Forms $C$ and $H$ were sprayed over tomato plants about two feet high in the greenhouse, but no infection nor leaf spotting took place.

\section{ISOLATION OF SINGLE-SPORE CULTURES AND EXPERIMENTS THEREWITH.}

During October, November, and December I919, single-spore cultures of all the forms were made. Each form was passed through the tomato fruit and back on to tomato agar, singlespore cultures being established on the latter by the dilution method. As soon as single-spore cultures of all the forms had been obtained, the following fourteen series of inoculations and culture experiments were carried out to obtain some idea of the characters of the various forms on different media with a view to their systematic arrangement.

All the forms were not used in every series, sometimes owing to lack of material. The following table shows in brief the results of these experiments. 
Table I. Cultures on tomato agar were always used.

Host or medium used

(I) Sterilised tomato stems in tubes

(2) Tomato plants; needle pricks made in stem

(3) Potato agar

(4) Melon plants in greenhouse. Needle pricks made in stem

(5) Cucumber plants in greenhouse. Needle pricks made in stem

(6) Carrots in the laboratory. Needle prick inoculations

(7) Apples (Cox's Orange) in the laboratory. Needle prick inoculations

(8) Potatoes in the laboratory. Needle prick inoculations

(9) Sterilised potato cores

(Io) Green grapes kept in an incubator at $27^{\circ} \mathrm{C}$. Needle prick inoculations

(II) Dox's medium (5) (30 grms. cane sugar per litre)

(I2) Dox's medium (I5 grms. cane sugar per litre)

(r3) Dox's medium (7.5 grms. cane sugar per litre)

(14) Green tomato fruits in the laboratory. Needle prick inoculations
Forms used

All except $G$, Very profuse growth of my$S$ and $U$

$B, C, D, E, H$, $K 2, L$ and $T$

All except $G, \quad$ Mycelium scanty. Fruiting $S$ and $U$ bodies usually formed sparingly

$B, D, K 2, L, T$ No infection

$B, L, T \quad$ No infection

$A, B, D, J \quad$ No infection

$B, J, L \quad$ No infection

$C, E, J, L$

$L$ formed a dry sunken canker with typical pycnidia and spores. $C, E, J$ without effect

All except $G$, Generally a profuse growth $S$ and $U$ of mycelium with a fair number of fruiting bodies

All except $G \quad$ No infection

and $S$

All except $G, \quad$ Mycelium generally profuse $S$ and $U$ and dark coloured, quite obscuring the fruit bodies

All except $G$ Mycelium less profuse, lighter colour, fruiting bodies plentiful

All except $G \quad$ Mycelium less profuse, fruiting bodies plentiful

All except $G$ All formed typical rots and $S$ except $U$

In the course of these experiments it was soon found that these forms of fungi took on great differences in growth-characteristics according to the medium used; with the exception of type $C$ it was impossible to pick out these forms by any feature which was constant throughout all the media and hosts tried.

The conclusion was reached that it was absolutely necessary to use a purely artificial medium like Dox's, if any attempt was to be made to put on record differences between such closely related species or varieties as were being used, which would have value for other workers. 
Some Tomato Diseases. F. T. Brooks and G. O. Searle. I79

In using Dox's medium it was found that the normal amount of cane sugar, i.e. 30 grms. per litre, produced a too profuse mycelial growth, so that fruit bodies, specially of the pycnidial type, were obscured and such details as the colour of the spore mass could not be determined.

The amount of sugar was therefore first modified to $15 \mathrm{grms}$. per litre and later to 7.5 grms. per litre. This latter medium appeared to give the most satisfactory results.

On duplicating the whole series on the medium containing 7.5 grms. sugar no appreciable difference could be discerned between the two tubes of each form, an effect which was not seen when working with other media such as tomato agar.

The formula used in this modification of Dox's medium was as follows:

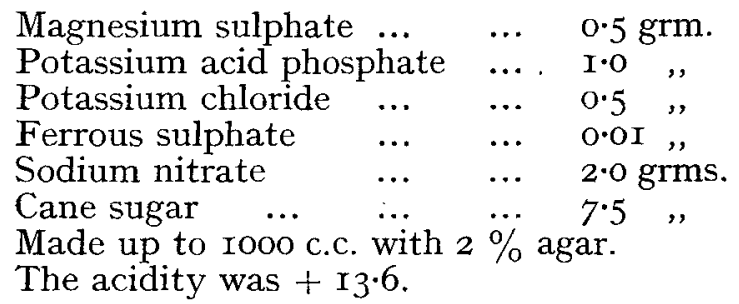

\section{DESCRIPTION OF THE MACROSCOPIC CHARACTERS OF THE VARIOUS FORMS ON TOMATO FRUITS.}

The following gives the appearance of these fungi on tomato fruits about ten days after inoculation:

Form A. A black spot roughly circular about $\frac{1}{2}-\mathrm{I}$ inch in diameter, slightly sunken towards the circumference, generally raised in the centre at the point of inoculation. Shades off in colour towards the uninjured part of the fruit. Very numerous black pycnidia aggregated round the centre and erumpent through the epidermis of the fruit, giving the surface a roughly punctate, carbonaceous appearance.

Form B. Large brown spot, with numerous brown pycnidia erumpent through the epidermis of the fruit.

Form C. Large brownish black spot, about one inch in diameter, raised in the centre and sunken towards the circumference. Very numerous, densely gregarious pycnidia, varying from brown to black in colour, covered with dull greyish pink, slimy, spore masses.

Form D. Watery-looking, rugged canker about one inch in diameter, entirely covered with closely aggregated black acervuli, surrounded by a circle of younger acervuli covered with pink spores. 
Form E. Large, light brown spot, not raised nor depressed, numerous light brown pycnidia.

Form $F$. Same appearance as $E$ but the pycnidia of a somewhat darker brown.

Form $H$. Same appearance as $F$.

Form $J$. Large, brownish spot, rather sunken below the remainder of the surface, numerous pycnidia varying from brown to black.

Form $K$. Large, rather watery-looking spot, completely covered with pink cushions of spores, later becoming blackish.

Form $K 2$. Similar to $K$, but later the pink cushions (acervuli) became black and the appearance was then similar to $D$.

Form L. Large canker covered with black pycnidia.

Form $M$. Large, rugged, brown canker covered with brown pycnidia.

Form N. Large canker covered with white mycelium and masses of pink Fusarium spores.

Form $P$. Large brown cankered spot, rather rugged surface, covered with brown pycnidia.

Form $Q$. Smooth, black spot, almost shiny surface, numerous pycnidia scarcely erumpent through the epidermis of the fruit.

Form S. Black acervuli formed with typical, pointed setae and large numbers of spores.

Form $T$. Large spot about $\mathrm{I}_{2} \frac{1}{2}$ inches in diameter, self coloured, not soft, no visible pycnidia but very numerous pink tendrils of spores projecting through the surface from pycnidia evidently subcutaneous.

Form $U$. The fungus spread only to a very slight extent when inserted into tomato fruits, and no fructifications were formed.

It would make this paper of undue length to include a full macroscopic description of these forms on all the different media used. For one thing, the composition of such media as tomato agar and potato agar varies considerably in different batches, and undoubtedly the macroscopic characters of the cultures vary with changes in the medium, so that the characters shown on a medium such as tomato agar or potato agar would probably not be of great value to other investigators. In the following description, therefore, only the microscopic characters on the third modification of Dox's medium, i.e. the one containing 7.5 grms. cane sugar per litre, are given, with occasional notes on special points shown on other media, since Dox's medium, being of a synthetic nature, can be duplicated at will with the knowledge that future batches will be of very close comparative chemical composition with the medium from which the present diagnoses were made. 
Some Tomato Diseases. F. T. Brooks and G. O. Searle. I8I

MACROSCOPIC CHARACTERS OF THE VARIOUS FORMS ON

DOX'S MEDIUM MODIFIED TO CONTAIN 7.5 GRMS. CANE SUGAR PER LITRE, WITH OCCASIONAL NOTES ON CHARACTERISTICS SHOWN BY THE FORMS ON OTHER MEDIA.

Form $A$. Aerial mycelium fairly plentiful, varying from white to grey. Medium not coloured, submerged mycelium hyaline. Pycnidia very numerous, black, small, more closely aggregated towards the middle of the culture, semi-erumpent. No visible spore mass. This form generally produced pycnidia very sparingly. The quantity of mycelium varied greatly on different media; on potato agar it was very slight with a few light brown pycnidia, whilst on Dox's medium with 30 grms. sugar per litre, the mycelium was very profuse and dark olive green in colour.

Form B. Aerial mycelium fairly plentiful, generally white but varying to light grey in colour, submerged mycelium hyaline. Pycnidia numerous, scattered, varying greatly in size, generally in the aerial mycelium, sometimes on the surface of the medium, black in colour. With potato agar, on the other hand, the mycelium was dark coloured and largely submerged in the medium, and numerous dark coloured appressoria were formed towards the edge of the culture; on tomato agar a dirty yellow-coloured spore mass was noticeable and on Dox's medium with 30 grms. sugar the mycelium was very profuse and almost black.

Form C. Aerial mycelium very slight, fulvous brown to grey. Pycnidia very numerous, chocolate brown in colour with a few pink spore masses. Pycnidia apparently seated on the surface of the medium. On Dox's medium with 15 grms. sugar per litre, the spore masses were very conspicuous as pink spots which coalesced all over the surface of the medium, whilst at the top and bottom of the culture were dark brown bands of aerial mycelium bearing the Alternaria form of spores; on potato agar, on the other hand, both mycelium and pycnidia were scanty, the latter being light brown in colour and almost entirely aggregated along the original inoculation streak. All the cultures were similar in showing scanty mycelial growth and early formation of pycnidia, the first being usually formed within 48 hours of the culture being made. The Alternaria form invariably appeared later and upon the drier portion of the culture. Sowings of the Alternaria spores were made and these produced pycnidia first and Alternaria later. Cultures made from single pycnospores also formed spores of Alternaria as well as pycnidia.

Form $D$. Aerial mycelium grey, tending to become matted.

M.s. 
Pink tinge at the surface of the medium. Submerged mycelium slight and hyaline. Black acervuli large and scattered, with numerous smaller black bodies, apparently sterile acervuli, which were scattered throughout the medium. On other media the cultures only differed in the numbers of acervuli.

Form $E$. Aerial mycelium very scanty, white; submerged mycelium hyaline, scanty; pycnidia and spore masses very numerous and both of a light brown or straw colour. Other cultures showed variations in the colour of the mycelium, but the pycnidia were always light brown in colour.

Form $F$. Aerial mycelium fairly plentiful, white, tending to be floccose. Pycnidia very numerous, light brown, particularly aggregated at the bottom of the culture. Spore masses infrequent, light yellowish brown in colour. In this case, the colour of the pycnidia varied greatly, as on tomato agar and sterilised tomato stem the pycnidia were almost black; this was not a matter of age of culture since, on Dox's medium, the pycnidia were still light brown in colour at the end of eight months.

Form $H$. Aerial mycelium, white, scanty at the top of the culture but denser at the base. Pycnidia numerous, dark brown, mainly aggregated at base of culture, on surface of medium or in aerial mycelium, larger than in $E$ and $F$. Spore masses few and light brown. Fairly similar characteristics were shown on the other media, the mycelium varying, however, from white to dark grey.

Form $J$. Aerial mycelium plentiful, white. Pycnidia few, large, brown, tending to be confluent; spore masses light brown to yellow. Pycnidia partly submerged in the medium. Generally, only few pycnidia were formed, except on potato cores and tomato stems, on which the number was large and their colour black.

Form $K$. Aerial mycelium plentiful, white to dark browngrey. Large aggregations of very dark-coloured submerged mycelium. No trace of fructifications. This form produced very few spores and in artificial cultures spores appeared only early in the development of the fungus and not on a distinct acervulus-at least no black acervuli were visible as in Form $D$; on tomato fruits the spores were aggregated on acervuli and were numerous, but the same dense cushion of mycelium covered with spores was not observed in any culture.

Form $K 2$. This culture was similar to $K$, except that the mycelium was more scanty. Here again no proper acervuli were formed in culture except in one on tomato agar where a few black acervuli were visible. The sporing stage, as in $K$, could be seen from the pink tinge taken on by the mycelium in the early stages. 
Some Tomato Diseases. F. T. Brooks and G. O. Searle. I83

Form L. Aerial mycelium, white, scanty, evanescent, adpressed to the medium. Pycnidia exceedingly numerous, brown, with light brown spore masses, generally half-submerged in the medium, some wholly submerged. This was a very constant form on all media, always showing very scanty mycelium and exceedingly numerous brown pycnidia.

Form $M$. Aerial mycelium plentiful, tending to be matted, greyish white. Pycnidia fairly numerous, scattered at the top of the culture and aggregated towards the bottom, brown to light brown in colour, with yellow brown spore masses. On other media the production of pycnidia was slight except on sterilised tomato stems, where they were very numerous and black in colour.

Form $N$. Aerial mycelium very scanty, evanescent, white. Large, confluent, salmon pink spore masses. Mycelium was always rather scanty except on potato cores and sterilised tomato stems, but the cultures were very distinct by reason of the large confluent masses of Fusarium spores.

Form P. Aerial mycelium very profuse, white, matted. Pycnidia very few, scattered, brown, large. On different media the pycnidia varied from brown to black.

Form $Q$. Aerial mycelium fairly plentiful, white, closely adpressed to the medium. Pycnidia very few, brown. Spore formation very sparse on all media.

Form S. Aerial mycelium very scanty and almost entirely evanescent. Acervuli very numerous, black, scattered all over the culture. In earlier stages the medium took on a pinkish tinge.

Form T. Aerial mycelium very scanty and evanescent, white. Pycnidia numerous, yellowish brown, later a red brown, entirely covered with profuse, pink spore masses. The colour of the pycnidia and spore masses varied considerably on various media; pycnidia dark brown on potato agar, light brown on tomato agar; spore masses dirty pink to salmon colour on tomato agar, brick red on potato cores.

Form U. Aerial mycelium profuse, grey, adpressed to the medium. No fructifications were produced by this form on any medium, which was disappointing as it was the only culture of an authentic Mycosphaeralla citrullina and so was important for comparative purposes.

Before discussing the microscopic characters of the various forms and comparing them with the herbarium and other material obtained, it will be convenient to divide them into groups.

The first and most important section, Group $A$, contains all the forms having a pycnidial type of fructification and probably belonging either to the genus Phoma or to the genus Diplodina. 
This Group $A$ includes the following forms:

Form $A$ : which is an authentic specimen of Phoma destructiva (Plowr.) C. O. Jamieson, from America.

Form $B$.

Form $C$ : which possesses an Alternaria form of spore as well as a pycnidial stage.

Forms $E, F, H, J$.

Form $L$ : which is pycnidial but shows differences from the other forms in its wider infective powers and greater percentage of septate spores.

Forms $M, P, Q$.

Form $T$ : which is a specimen of Ascochyta Pisi Lib.

Form $U$ : no fructifications were formed by this.

GROUP $B$ consists of those forms which can be placed either in the genus Colletotrichum or Gloeosporium, and includes:

Form $D$ : which is an authentic culture of Colletotrichum phomoides (Sacc.) Chester from America.

Forms $K, K 2$ and $S$.

Group $C$ consists only of Form $N$ which is a typical species of the genus Fusarium.

In studying the various forms of Group $A$ it was found that these showed great variability in characters which are generally looked upon as specific, such as size of spores, septation of spores, guttulation and shape of spores, and one was forced to the conclusion that a number of so-called species in genera like Phoma, Ascochyta and Diplodina, are nothing more than varieties of one and the same fungus. In fact, it is difficult to see how a final decision is to be made in many cases unless the investigator has the opportunity of carrying out a large number of cultural trials on artificial media and also cross inoculations on to various hosts. A comparison of the microscopic characters found in the pycnidial forms included under Group $A$ will now be made:

MICROSCOPIC CHARACTERISTICS OF THE VARIOUS FORMS

INCLUDED IN GROUP $A$ (PYCNIDIAL FORMS) ON TOMATO FRUITS AND CULTURE MEDIA.

Form $A$.

Description given by Miss Jamieson (q.v.)

Pycnidia. Scattered to aggregate, most abundant towards centre of spot, subcutaneous later erumpent, glabrous, brownish black, subglobose, slightly papillate,
Description of authors' cultures

Pycnidia varying greatly in size, sometimes single, sometimes compound with two or more ostioles (sometimes as many as four). Pycnidia 
Some Tomato Diseases. F. T. Brooks and G. O. Searle. 185

Description given by
Miss Jamieson (q.v.)

not beaked, ostiolate (usually one sometimes two pores), 30$350 \mu$ in diameter. Pycnidial wall thin, outer cells brown, inner cells hyaline; delicate filiform basidia arising from inner cells.

PycNospores. Issue in coils through ostiolum forming a shiny flesh-coloured exudate...hyaline.

Shape. Sub-cylindrical to sub-globose, rarely tapering.

Septation, Continuous.

Guttulation. 2-guttulate.

SIZE. $\quad 2.8 \mu-8.5 \mu \times 1.7 \mu-3.4 \mu$.
Description of authors cultures

usually globose but irregular shapes seen, light yellowish brown, ostiole surrounded by a dark circle. Erumpent through the epidermis.

Issue in coils through the ostiolum. Hyaline.

Sub-cylindrical with rounded ends, occasionally slightly asymmetrical.

Non-septate.

Rarely faintly biguttulate. $3.5 \mu-5.5 \mu \times 2 \mu-3 \mu$. Very uniform in size.

\section{Form B.}

Pycnidia. Pycnidial characters as to shape, size and colour varied so much as to seem unreliable for diagnostic purposes and are omitted in this and other forms.

Pycnospores. Issue in coils through the ostiolum. Hyaline.

Shape. Ovate, usually slightly asymmetrical on one side and often slightly pointed at one end.

Septatron. Non-septate.

Guttulation. Bi-guttulate.

Size.

$3.5 \mu-7.5 \mu \times 2 \mu-3.5 \mu$ (20 measurements). Dark, thickwalled appressoria were also formed.

\section{Form $C$.}

Pycnospores. Issue in coils through ostiolum. Hyaline.

SHAPE. Ovate with a tendency to pointed ends.

SEPtation, Non-septate.

Guttulation. Very faintly biguttulate, except on Dox's medium, where they were strongly biguttulate and the average size was larger.

SizE. $\quad 3 \mu-7.5 \mu \times 2 \mu-3.5 \mu$ (20 measurements). An Alternaria form of spore was borne on the same mycelium, a large browncoloured multi-septate spore of greatly varying shape and size. There were also numerous, thick-walled, dark coloured spore-like bodies averaging $8 \mu \times 4 \mu$ round the edges of the cultures; these were not observed to germinate or become detached from the mycelium and they were taken to be a kind of appressorium formed under cultural conditions.

\section{Form E.}

Pycnospores. Issue in coils through ostiolum. Hyaline.

Shape.

Irregular, usually ovate to cylindrical, usually with rounded ends, but sometimes one end pointed, occasionally slightly curved. 
Septation. Usually non-septate, but about ro-20 \% I-septate, generally slightly constricted at the septum.

Guttulation. Very rarely bi-guttulate.

SIzE.

$3.5 \mu-9 \mu \times 2 \mu-3.5 \mu$ non-septate. $7.5 \mu-$ II $\mu \times 3 \mu-3.5 \mu$ Iseptate (20 measurements).

\section{Form $F$.}

Pycnospores. Issue in coils through ostiolum. Hyaline.

SHAPE. Ovate to cylindrical with rounded ends, occasionally slightly curved.

Septation, Usually non-septate, but $5 \%$ of the spores from a tomato agar culture were I-septate, and on Dox's medium between $5 \%$ and ro $\%$ were $r$-septate. Septate spores scarcely, if at all, constricted at the septum. In this form a spore mass which had been extruded some time from a pycnidium showed up to $50 \%$ of the spores septate.

Guttulation. About $40 \%$ of the spores were bi-guttulate.

SIzE.

$4 \mu-8.5 \mu \times 2.5 \mu-4 \mu$ non-septate. $7 \mu-9 \mu \times 3 \mu-3.5 \mu$ I-septate (20 measurements).

Discarded.

\section{Form $G$.}

\section{Form $H$.}

Pycnospores. Issue in coils through ostiolum, hyaline.

Shape.

Ovate to sub-cylindrical, all very uniform in shape and size.

Septarion. Non-septate.

Guttulation. Bi-guttulate.

SIZE.

$3.5 \mu-6.5 \mu \times 2.5 \mu-3.5 \mu$ (20 measurements).

\section{Form $J$.}

Pycnospores. Issue in coils through ostiolum, hyaline.

ShaPE. Ovate to cylindrical with rounded ends, occasionally slightly curved.

Septation. Usually non-septate, about 5-Io \% I-septate, scarcely, if at all, constricted at the septum. Spores from a spore mass on Dox's medium were about $30 \%$ I-septate.

Guttulation. Occasionally faintly bi-guttulate.

Size.

$3.5 \mu-9 \mu \times 2.5 \mu-3.5 \mu$ non-septate. $8 \mu-\mathbf{I 0 . 5} \mu \times 3 \mu-4 \mu \quad \mathbf{I}$ septate (20 measurements).

\section{Form L.}

Pycnidia. Sometimes malformed and assuming a tubular form a millimetre or more long in culture. Frequently with more than one ostiole.

Pycnospores. Issue in coils through ostiolum, hyaline.

Shape.

Cylindrical, rounded ends, some slightly curved, some ovate. Sizes varying considerably.

Septation. About $40 \%$ I-septate, the remainder non-septate. Always constricted at the septum. On potato agar up to $80 \%$ I-septate.

Gutrulation. Occasionally bi-guttulate.

SIzE.

$4.5 \mu-\mathrm{II} \mu \times 2.5 \mu-5 \mu$ non-septate. $7.5 \mu-\mathrm{I} 2.5 \mu \times 3.5 \mu-4.5 \mu$ I-septate (20 measurements). 
Some Tomato Diseases. F. T. Brooks and G. O. Searle. 187

\section{Form $M$.}

Pycnospores. Issue in coils through ostiolum, hyaline.

SHAPE. Ovate to sub-cylindrical, rounded ends, very varied in size and shape.

Septation. Usually non-septate, about $20 \%$ I-septate and generally constricted at the septum. Occasionally 2 -septate.

Gurrulation. No guttules.

Srze.

$4.5 \mu-\mathrm{I} 2 \mu \times 2 \mu-4 \mu$ non-septate. $9 \mu-\mathrm{I} 7 \mu \times 2.5 \mu-5 \mu$ I-septate. $5 \mu \times 3.5 \mu$ (20 measurements).

\section{Form $P$.}

PycNospores. Issue in coils through ostiolum, hyaline.

SHAPE. Ovate to sub-cylindrical with rounded ends, occasionally slightly curved.

Septation. Usually non-septate, about io \% I-septate, not constricted at the septtm. Percentage of septate spores rapidly increases with age.

Guttulation. Very occasionally a single guttule.

Size.

3. $5 \mu$-ro $\mu \times 2 \mu-4 \mu$ non-septate. $8 \mu$-I $4 \mu \times 3 \mu-4 \mu$ I-septate (20 measurements).

\section{Form $Q$.}

Pycnospores. Issue in coils through ostiolum, hyaline.

SHAPE. Ovate to cylindrical, one end usually and sometimes both ends pointed.

Septation. Non-septate.

Guttulation. Generally bi-guttulate.

SizE. $\quad 4 \mu-8 \mu \times 2 \cdot 5 \mu-3 \cdot 5 \mu$ (20 measurements).

\section{Form $T$.}

This was a specimen of Ascochyta Pisi Lib.

Pycnospores. Issue in coils through ostiolum, the coil often attaining a length of two or three millimetres. Hyaline, often very vacuolate, but non-vacuolate in perfectly fresh spores.

Shape. Cylindrical with rounded ends, often slightly curved.

Septation. $\quad 95 \%$ I-septate, occasionally 2 or 3 -septate, not constricted at the septum, except in perfectly fresh spores which were slightly constricted.

Guttulation. Indefinite.

SIzE,

ro.5 $\mu-17.5 \mu \times 2.5 \mu-4.5 \mu$ I-septate. I $4.5 \mu \times 3.5 \mu$ 2-septate. $24 \mu \times 4.5 \mu$ 3-septate. $8 \mu \times 3 \mu$ non-septate (20 measurements).

The systematic position of species of the genera Phoma, Ascochyta, and Diplodina is difficult to determine.

The chief difference between the genera Phoma and Diplodina is that, according to systematists, the spores of Phoma are non-septate and those of Diplodina I-septate.

A study of the herbarium specimens does not tend to make matters easier as will be seen by the following descriptions: 
Herbarium Specimen I. MycosphaERELIA CITRUILINA (reputed) on tomato stem, England (only pycnidial stage present).

Pycnospores. Ejected in coils from ostiolum. Spores rather shrunken and mis-shapen through age.

Shape. Very irregular.

Septation. Usually non-septate, about $20 \%$ I-septate: usually constricted at the septum.

Guttulation. About $50 \%$ bi-guttulate.

SizE. $\quad 5, \mu-$ I I $\mu \times 3 \mu-4 \mu$ non-septate. $9 \mu-$ IO $5 \mu \times 3 \mu-4 \mu$ I-septate.

Herbarium Specimen 2. MYcosphaERELla citrullina (reputed) as No. I (only pycnidial stage present).

Pycnospores. Ejected in coils from ostiolum. Hyaline.

SHAPE. Irregular, often constricted at the centre, some slightly curved, some pear-shaped.

Septation. Usually non-septate, only about $5 \%$ I-septate.

Gutrulation. Occasionally indistinctly bi-guttulate.

SIzE. $\quad 4 \mu$-IO $\mu \times 2.5 \mu-3.5 \mu$ non-septate. $8 \mu$-IO.5 $\mu \times 3.5 \mu$ I-septate.

Herbarium Specimen 3. Mxcosphaerella citrullina (C. O.Sm.)

Gross., on water-melon stem (pycnidial stage) from America.

Pycrospores. Ejected in coils through the ostiolum, the pore of the ostiolum seemed narrower than usual and the spores were ejected in a coil only three or four spores wide. Spores hyaline.

SHAPE. Very regular, cylindrical, rounded at the ends, very rarely slightly curved.

SEPTATION. Usually non-septate, rarely faintly I-septate (about ro \%).

Guttulation. Indefinite.

SizE. $\quad 5 \mu-\mathrm{I} 4 \mu \times 2.5 \mu-5 \mu$ non-septate. Io $\mu-13 \mu \times 3.5 \mu-4 \mu$ I-septate.

Herbarium Specimen 4. Mycosphaerella Citrullina (C. O. Sm.) Gross., on water-melon, same source as No. 3 (pycnidial stage).

Pycnospores. Ejected in coils through ostiolum, hyaline.

SHAPE. Cylindrical, rounded ends, sometimes slightly curved.

SEPTATION. Always I-septate, occasionally 2-septate.

Guttulation. Generally bi-guttulate.

SizE. IO. $\quad$ L $\mu-17 \mu \times 3-3.5 \mu$ I-septate. I4 $4-15 \mu \times 3.5 \mu-4 \mu \quad$ 2-septate.

Herbarium Specimen 5. MycosphaERELla crtrullina Gross. (reputed), on tomato stem, England; in the Kew Herbarium (pycnidial stage only).

Pycnospores. Ejected in coils through the ostiolum, hyaline.

SHAPE. Cylindrical, rounded ends, regular. Some very slightly curved.

Septation. Usually non-septate, about $20 \%$ I-septate, not constricted at the septum.

Guttulation. No guttules.

SizE. $\quad 4 \mu$-ro $\mu \times 2.5 \mu-3.5 \mu$ non-septate. $8.5 \mu-10 \mu \times 3 \mu-3.5 \mu$ Iseptate. 
Some Tomato Diseases. F. T. Brooks anä G. O. Searle. 189

Herbarium Specimen 6. MycosphaERELIA Citrulina (reputed), on tomato stem, England; in the Kew Herbarium (pycnidial stage only).

Pycnospores. Ejected in coils through the ostiolum, hyaline.

ShAPE. Mainly cylindrical with rounded ends, but irregularly shaped and curved, spores numerous.

Septation. About $60 \%$ I-septate, sometimes slightly constricted at the septum.

Guttulation. Few spores bi-guttulate, a few one-guttulate.

SIZE. $\quad 6 \mu$-IO $\mu \times 2.5 \mu-4 \mu$ non-septate. $7.5 \mu-$ II $\mu \times 3 \mu-4 \mu$ I-septate.

Herbarium Specimen 7. Mycosphaerella Citrullina (reputed), on lower part of melon stem, England, in the Kew Herbarium (pycnidial stage only).

Pycnospores. Very few spores were obtained from this specimen and the mode of ejection from the pycnidium could not be determined.

SHAPE. Cylindrical with rounded ends.

Septation. All except 3 spores (I5 was total number seen) were very faintly $x$-septate, no constriction at septum.

Gutrulation. No guttules.

Srze. $\quad 8 \mu-10 \mu \times 2.5 \mu-3.5 \mu$ I-septate. $7 \mu-9 \mu \times 3 \mu$ non-septate.

Herbarium Specimen 8. Phoma Lycopersici Cke., on tomato stem, England. This was Cooke's type specimen in the Kew Herbarium.

Pycnidra. Pycnidia brown, roughly spherical to triangular, average diameter I $10 \mu$. Ostioles usually I, sometimes more. A few compound pycnidia seen. Only a few spores were obtained.

Pycnospores. Hyaline, but the mode of ejection from the pycnidium could not be determined.

Shape. Cylindrical with rounded ends, very regular.

Septation. $90 \%$ I-septate.

Guttulation. No guttules.

SIZE. $\quad 8 \mu-\mathbf{I} 2 \mu \times 2.5 \mu-4 \mu$ I-septate. $7 \mu-$ I I $\mu \times 2.5 \mu-3.5 \mu$ nonseptate (20 measurements).

Herbarium Specimen 9. Diplodina citrullina (reputed), on dried stems of cucumber, from Germany, 1908; in the Herbarium of the British Museum.

Pycnidia. Pycnidia light brown with a darker band surrounding the lighter-coloured ostiole.

Pycnospores. Hyaline, but the mode of ejection from the pycnidium could not be determined.

SHAPE. Not cylindrical.

Septation. About $40 \%$ r-septate.

Guttulation. No guttules.

Size. $\quad 5-9 \mu \times 2.5 \mu-3.5 \mu$. 
Herbarium Specimen io. Mycosphaerella citrullina (C. O. Sm.) Gross., on cucumber fruit collected in Florida, IgI7. This was the perithecial stage, but no spores were obtainable from this material.

From a study of these herbarium specimens it is apparent that even these do not conform with the usually accepted ideas of the genera Phoma, Ascochyta and Diplodina. In fact, taking into consideration the lack of any perithecial stage it would seem that the two herbarium specimens from the Ministry of Agriculture (No. I and No. 2) and those from the Kew Herbarium (Nos. 5, 6, and 7 ) should certainly not be placed in the genus Mycosphaerella.

The circumstances point to the fact that, contrary to the usually accepted idea, the species Mycosphaerella citrullina (C. O. Sm.) Gross. (6) has not yet been found in England. It should therefore be deleted from the list of British species known at present. The cultural characters and general behaviour of authentic specimens of Mycosphaerella citrullina from America, do not agree with any of the fungi isolated from tomatoes in this country.

Cooke's fungus, Phoma Lycopersici, should certainly be placed in a different genus (Diplodina) as nearly all the spores are septate.

Taking into consideration the extreme variability of the genera Phoma and Diplodina we have classified the forms under investigation in the following manner, although it is doubtful if a sharp line can be drawn between Series I and Series 2:

Series 1.

True Phoma destructiva (Plowr.) C. O. Jamieson as defined by Form $A$, an authentic culture.

Forms $B, H$ and $Q$.

So far in this country these forms have only been found on tomato fruits, although in America this fungus is able to cause also a disease of the leaves and stems.

\section{Series 2.}

Intermediate in type between Phoma and Diplodina. Septation of spores variable, but there are always some spores septate and the spores are usually larger than in Group $A$.

Forms $E, F, J, M, P, L$.

Included in this group also are herbarium specimens $I, 2,5$, 6,7 and 8 . These forms have been found both on the fruit and on the stem of tomato plants. They differ considerably as regards pathogenicity to the stems under experimental conditions. 
Some Tomato Diseases. F. T. Brooks and G. O. Searle. IgI

These forms are closely allied to one another and probably only represent strains of the same aggregate species. In the present state of our knowledge and methods of analysis, it is considered advisable to attempt to give names only to aggregate species of fungi and not to the smaller elementary species or strains of which the aggregate species consist. It has long been recognised by those who grow fungi in pure culture that many species show numerous forms which can only be differentiated one from the other by minor cultural characters, but under present conditions mycological systematy would become altogether too unwieldly if attempts were made to name these different cultural forms.

It is proposed to place this group of forms as well as herbarium specimens Nos. I, 2, 5, 6, 7 and 8 , in the genus Diplodina. It has already been pointed out that, as regards these fungi, the generic distinction between Phoma and Diplodina has broken down, but in view of the considerable percentage of septate spores in the pycnidia, Diplodina has been chosen as the generic name. The name Ascochyta is not used as the pycnidia do not occur in spots. Two species of Ascochyta have been recorded on decaying tomato leaves(r3), $A$. Lycopersici Brun. with spores constricted at the middle, and $A$. socia without median constriction. These species have not been seen by us and have not yet been recorded in Britain. A. Lycopersici Brun. may be identical with the fungus now under consideration, but if so, it is preferable to place it in the genus Diplodina. Cooke's name Phoma Lycopersici(4) is deleted. Plowright's Sphaeronema Lycopersici(12) found on tomato fruits may be identical with this, but it has not been possible to obtain the original specimen. It is doubtful whether Plowright* placed his fungus in the right genus as the neck of the pycnidium as figured in his paper is extremely short, and there is no mention of it in the diagnosis. The spores are about the same size as in our forms and the absence of septation is not remarkable. In view of these considerations and of the apparent loss of the type specimen, it seems advisable also to delete the name Sphaeronema Lycopersici.

In considering the systematic position of this fungus, $\mathrm{Mr} \mathrm{J}$. Ramsbottom of the British Museum-to whom we are much indebted for help in the matter of nomenclature-called our attention to the description of Diplodina Lycopersici Hollós in Saccardo's Sylloge Fungorum(13). Although it has not been

* Since this was written, Mr W. B. Grove informs us that Plowright's idea of Sphaeronema depended upon the presence of a "globule" of extruded spores at the mouth of the pycnidium, and not upon the presence of a "beak" as understood by Saccardo. 
possible to examine this type specimen, which is in Hungary, the description, meagre as it is, fits in well with the fungus now under consideration; these fungi are therefore probably identical. It is thought advisable, however, to amplify Hollós' description, and the fungus will be named Diplodina Lycopersici (Cooke) Hollós emend. Brooks and Searle*.

Diplodina Lycopersici (Cooke) Hollós emend. Brooks and Searle.

Pycnidia scattered to aggregate, subcutaneous but subsequently erumpent, glabrous, brown to brownish-black, subglobose, slightly papillate, ostiolate (usually one sometimes 2-3 pores), IOO-270 $\mu$ in diameter; pycnospores issuing in coils through the ostiolum, forming a dirty white to flesh-coloured exudate; hyaline; continuous to I-septate (the percentage of septate spores is very variable), slightly constricted at the septum, 2-guttulate, or devoid of guttules, 4.5-17 $\mu \times 2.5-5 \mu$ (average $9 \cdot 4 \mu \times 4 \mu$ ), sub-cylindrical, produced singly as unbranched conidiophores. No definite stroma; no perithecial stage observed. Parasitic on green and ripe fruits of tomatoes, causing a soft rot, also on the stems, especially just above soil level.

It is considered that the fungus, isolated both from tomato stems and tomato fruits, which was the subject of investigation by one of us(2) some years ago was identical with this. It was then shown that the so-called tomato "canker" fungus was capable of causing a rot of the fruit, and that the same fungus isolated from rotting fruits was able to induce a "canker" of the stem $f$.

Series 3 .

Pycnidial form accompanied by Alternaria spores on the same mycelium.

Form $C$.

It is proposed to name the fungus obtained from tomato fruits Phoma alternariaceum Brooks and Searle.

\section{Phoma alternariaceum Brooks and Searle.}

Pycnidia aggregate, glabrous, brown to black, subglobose, slightly papillate, ostiolate (usually one, sometimes two pores),

* Since this paper was written, a description of tomato "canker" as it occurs in Germany has appeared (Klebahn, N., "Der Pilz der Tomatenstengelkrankheit und seine Schlauchfruchtsform," Zeitschrift für Pflanzenkrankheiten, xxxI, I92I, P. I). Klebahn also refers the fungus to Diplodina Lycopersici Hollos. He has, moreover, found the perithecial stage, which he names Didymella Lycopersici.

$\uparrow$ During the summer of 1921 , the stem canker form of this disease was received both from this country (through $\mathrm{Mr} \mathrm{A}$. D. Cotton) and from Holland (through Dr C. Schoevers). In each the fungus was identical with Diplodina Lycopersici (Cooke) Hollós. 
Some Tomato Diseases. F. T. Brooks and G. O. Searle. I93

Ioo-250 $\mu$ in diameter; pycnospores issuing in coils, through the ostiolum, forming a flesh-coloured exudate; hyaline, continuous, sometimes faintly bi-guttulate, $3-7 \cdot 6 \mu \times 2-3.5 \mu$ (average $6 \mu \times 3 \mu$ ), ovate with a tendency to pointed ends, produced singly on unbranched conidiophores. Pycnidia accompanied by aerial mycelium bearing spores of the Alternaria type produced in chains. Alternaria spores $40-80 \mu \times \mathrm{I} 2-18 \mu$, multiseptate, dark brown. On green and ripe tomato fruits, causing a rot.

The following diagnosis in Latin has been kindly drawn up by Mr Gepp and Mr Ramsbottom of the British Museum:

Phoma alternariaceum Brooks and Searle.

Pycnidiis aggregatis, glabris, brunneis atrisve, subglobosis, papillulatis, ostiolatis, poro (interdum poris duobus) pertusis, IOO-250 diam.; sporulis poro erumpentibus et cirrum roseolum protrudentibus, hyalinis, continuis, interdum obscure bi-guttulatis, $3-7.5 \mu \times 2-3.5 \mu$ (plerumque $6 \mu \times 3 \mu$ ), ovatis utrinque subacutis, e sporophoris simplicibus singulariter orientibus.

Pycnidiis mycelio aerio sporas typi Alternariae catenatis gerenti se sociantibus. Sporis Alternariae $40-80 \mu \times 12-18 \mu$, multiseptatis, atrobrunneis.

In Lycopersici fructibus viridibus maturisque, et pulpam putrefaciente.

In consulting the literature on Alternaria and Phoma, only two species of the latter have been found, in the life-cycle of which an Alternaria form has been described. These are two saprophytic species, Phoma Richardiae and Phoma fictilis mentioned by Miss Westerdijk and Miss van Luijk(x6) as having been grown by them. Many years ago, Kohl (8) in trying to clear up the obscurities concerning the spore forms of Pleospora herbarum, found a fungus, the pycnospores of which gave Alternaria spores as well as pycnidia in pure culture, but this species was not named, nor was it genetically connected with the Pleospora. It is interesting to note in this connection that Brefeld(r) found Alternaria stages, but not pycnidia, in the life-history of Pleospora vulgaris and Pleospora infectoria, while in Pleospora herbarum the accessory spore form was Macrosporium commune.

Some years ago Massee(xo) described a disease of tomato fruits caused by Macrosporium tomato and stated that pycnidia forming hyaline conidia accompanied the multiseptate spores, although no proof was brought forward that the two spore forms were genetically connected. In our investigations, species of Macrosporium have frequently been seen on diseased tomato fruits but upon isolation have always proved to be non-pathogenic. It seems likely that Massee's account of a tomato fruit 
disease was based upon a mixture of forms. In America it has been shown by Rosenbaum and Sando* that Macrosporium tomato Cke. may be the cause of a disease of uninjured tomato fruits.

\section{Series 4.}

This includes the forms $K, K 2$, and $S$ with the authenticated culture of Colletotrichum phomoides (Sacc.) Chest. (Form D).

As has been noted by Shear and Wood(15 P. 64) in dealing with the ascomycetous genus Glomerella, the conidial stage (Gloeosporium or Colletotrichum) shows great variability in its mode of formation and in morphological characters. In some cultures the conidia are borne on scattered conidiophores and in others large compact acervuli occur. Later these authors point out that setae are also a variable factor, being entirely absent in some cultures and present in others.

This variability was also noted by us in the four forms studied, and again, as in Series No. 2, makes the taxonomic arrangement of the forms very difficult.

In comparing the forms $K, K 2$, and $S$ with the authenticated culture (D) of Colletotrichum phomoides (Sacc.) Chest.(3) it was found that form $S$ was identical with the latter, except that setae were not always produced in artificial media, although when transferred to tomato fruits setae were abundantly formed. The acervuli varied from $180-360 \mu$ in diameter and the conidia were borne at the apex of short branched conidiophores. The conidia were usually cylindrical with rounded or slightly pointed ends, very regular in shape and size, and always unicellular. The cell contents were very granular.

The great majority of conidia were uniform in size at 2I $\mu \times 4 \mu$, though conidia were seen varying between I $4 \mu$ to $24 \mu \times 3 \mu$ to $4.5 \mu$. This form can therefore be undoubtedly diagnosed as Colletotrichum phomoides (Sacc.) Chest., and is, we believe, its first recorded appearance in England.

The forms $K$ and $K \mathbf{2}$ were identical one with the other but both slightly differed from forms $D$ and $S$, since, on artificial media large compact black acervuli were very seldom formed, the conidia being borne on cushion-like loose aggregations of conidiophores. Spore-formation seemed to be much more profuse than in the other forms, as the spores were produced in such abundance that the whole surface of the fruit was covered with pink masses of conidia almost coalescing one with another. Some conidia were very slightly curved; they were all nonseptate, very uniform in size and vacuolate. Setae were not observed. The size of the conidia in $K$ varied from $19 \mu$ to

* Rosenbaum, J. and Sando, C. E. Correlation between size of fruit and its relation to infection with Macrosporium tomato. Amer. Journ. Bot., I920. 
Some Tomato Diseases. F. T. Brooks and G. O. Searle. 195

$30 \mu \times 5 \mu$ to $8 \mu$, and of $K 2$ from $\mathrm{I}_{4} \mu$ to $30 \mu \times 5 \mu$ to $7 \cdot 5 \mu$, 20 measurements being taken in each case.

Mention has already been made that form $K 2$ produced typical acervuli on one artificial medium, so that it seems probable that these two forms can also be provisionally included under the species Colletotrichum phomoides.

\section{Series 5 .}

Series 5 consists only of form $N$ which was a typical species of Fusarium.

On Dox's agar, the colour of the spores in mass was orange salmon. The spores were crescent-shaped with pointed ends, $2-4$ times septate, $3-4 \mu \times 24-36 \mu$. When fully mature, one cell of the spore was often thick-walled and apparently functioned as a resting spore. Two species of Fusarium are recorded by Saccardo (13) as occurring on tomato fruits, F. aurantiacum Link, and F. oxysporum Schlecht. var. Lycopersici Sacc., but in the absence of comparative cultures, it is impossible to identify the species. It is probable that many species of this genus would cause a rot of tomato fruits if inserted in them through wounds, and in fact a pure culture of Fusarium caeruleum obtained from potatoes, produced a soft rot.

\section{GENERAL CONSIDERATIONS.}

It would appear from this review of a number of forms of fungi parasitic on the tomato fruit that the whole question of the taxonomy of difficult genera like Phoma, Ascochyta, Diplodina, Colletotrichum and Gloeosporium is one requiring considerable attention from systematists. At present the species in these genera are almost numberless and seem to be added to on very slender grounds and without much regard to the true relationships between them, which can only be determined by careful cultural work. To add new species indiscriminately on the grounds of host relationship, or on a variation in some small morphological detail, which if studied in cultural form will often turn out to be within the "experimental error" or ordinary range of variability, is much to be deplored and adds largely to the difficulties of later investigators. In the forms here investigated, this variability was found to be very marked, especially in such morphological details as septation of spores, a character often looked upon as specific and one in which some systematists beg the question by adding such phrases as "becoming septate later" or "the septation is tardy in appearing." 
SUMMARY.

Various rots of tomato fruits and certain diseases of the stems of tomato plants have been investigated. These fruit rots commonly occur both on imported and upon home-grown fruit, and are caused by several different fungi about the identity of which there has been much uncertainty. The fungi isolated from rotten tomatoes have been compared with authentic cultures of certain presumably identical or closely related fungi from the United States. One of the rots is caused by Phoma destructiva, the British form of which is identical with that from America. Another of these rots is produced by a fungus which has hitherto passed in this country under the name of Mycosphaerella citrullina, but which is certainly not identical with the American fungus of that name. The British fungus which has hitherto been mistaken for this and which causes tomato stem "canker" as well as a fruit rot, appears to be identical with Diplodina Lycopersici Hollós which name also replaces Phoma Lycopersici Cooke. It has been considered advisable to amplify Hollós' description and the fungus is therefore named Diplodina Lycopersici (Cooke) Hollós, emend. Brooks and Searle. Another pycnidial fungus, found only once as the cause of a tomato rot, is associated with an Alternaria stage, and the name proposed for this fungus is Phoma alternariaceum Brooks and Searle. Finally, various strains of Gloeosporium and Colletotrichum parasitic on tomatoes have been isolated. One of these fungi is identical with the American Colletotrichum phomoides (Sacc.) Chester, and probably all of these forms are thus best grouped.

The desirability of undertaking cultural sudies of fungi belonging to such genera as Phoma, Diplodina, and Colletotrichum as an aid in the diagnosis of species, is emphasised.

\section{POSTSCRIPT.}

Since this paper went to press, Petrak, in a note "Úber die Schwarzfäule der Tomaten" (Annales Mycologici, I921, p. I7), describes a fungus occurring on the leaves, stems, and fruits of the tomato, which he considers identical with Plowright's Phoma destructiva, but which he now names Diplodina destructiva (Plowr.) Petrak, because of the uni-septate character of the pycnospores formed on the leaves and stems although the spores are almost entirely non-septate in pycnidia on diseased fruits. Petrak's survey of the literature on this and allied tomato diseases is very incomplete, and, in the absence of inoculation and cultural experiments, it is by no means certain that he was dealing with one fungus only. As pointed out in our paper, it is doubtful whether a sharp line can be drawn between Phoma destructiva (Plowr.) C. O. Jamieson, and Diplodina Lycopersici (Cooke) Hollos, but in view of the above considerations and of the constantly non-septate character of the spores obtained both by Miss Jamieson and ourselves from certain forms of fruit disease, even under cultural conditions, it seems desirable to retain both these names. As stated previously, the generic distinctions between Phoma and Diplodina seem to have broken down in this group of fungi, and we appear to be dealing here with a series of closely-related forms, rather than with clearlydefined species. 


\section{BIBLIOGRAPHY.}

(I) BREFELD, O. Untersuchungen aus dem Gesammtgebiete der Mykologie, Heft $\mathrm{X}$.

(2) Brooks, F. T. and Price, S. R. A disease of tomatoes. New Phyt. vol. XII, T9I3.

(3) Chester, F. D. The ripe rot or anthracnose of tomato, Colletotrichum phomoides, Sacc. 6th Ann. Rep. Delaware Coll. Agric. Expt. Stn. I894.

(4) Cooke, M. C. New British Fungi. Grevillea, vol. xIIr, I885, p. 94.

(5) Dox, A. W. The intracellular enzymes of lower fungi, especially those of Penicillium camemberti. Journ. Biol. Chem. I909, vol. vi, p. 46r.

(6) GrossenBacher, J. G. A Mycosphaerella wilt of melons. New York Agric. Expt. Stn. Tech. Bull. No. 9, I909.

(7) IAmieson, Clara O. Phoma destructiva, the cause of the fruit rot of the tomato. Journ. Agric. Research, vol. IV, I9I 5.

(8) Kонг. Über den Polymorphismus von Pleospora herbarum (Tul.). Bot. Centralbl. Bd. xVI, p. 26, I883.

(9) Massee, G. Cucumber and Tomato canker. Kew Bulletin, I 909.

(Io) - Diseases of cultivated plants and trees, London, rgio.

(I I) Peck, C. H. Report of the Botanist, 4oth Ann. Rep. New York State Museum, I 886, p. 57.

(12) Plowright, C. B. On the fungoid diseases of the Tomato. Gard. Chron., I881, p. 260.

(I3) Saccardo, P. A. Sylloge fungorum, vols. III, IV, $x$ and $x$ Xit.

(I4) Schoevers, T. A. C. De tomatenkanker. Tijdschrift over Plantenziekten, $\mathrm{XxV}$, I919, p. I74.

(I5) SHeAR, C. L. and WOOD, ANNE K. Studies of fungous parasites belonging to the genus Glomerella. U.S. Dept. Agric., Bur. Plant Industry, Bull. 252, I9r3.

(16) WesterdiJK, J. and VAN LuiJK, A. Die Kultur der Phoma Arten. Mededeelingen uit het Phytopathologisch Laboratorium "Willie Commelin Scholten," Amsterdam, I920, p. 26. 